\title{
Current Surgical Options for Mammary Tumor Removal in Dogs
}

\begin{abstract}
Mastectomy remains the primary treatment of mammary tumors in dogs. The type of mastectomy seems not to have any effect on survival. Surgery aims at complete tumor removal with clean histological margins by using the simplest technique. Unilateral mastectomy is currently recommended for the prevention of second tumor development associated with a regional mastectomy. Dead space elimination and management of tension in the incision line are the most important issues conceming mastectomy closure and may be accomplished using different techniques. Ovariohysterectomy seems to affect survival if performed in less than 2 years time or at the same time with mastectomy. Analgesia is an important part of the postoperative management of patients undergoing mastectomy. Most common complications associated with mastectomy include seroma/hematoma, wound infection, dehiscence of the incision, hindlimb edema, and tumor recurrence.
\end{abstract}

\section{Introduction}

Surgical resection is the current gold standard therapy for mammary gland tumors in dogs and considered to be the single most effective method to attain local tumor control with the exception of inflammatory carcinoma or presence of distant metastases [1-6]. As long as the type of surgical resection in dogs seems not to affect survival surgery is aiming at entire tumor removal with clean histological margins using the simplest technique [1-3]. Determination of the extent of surgical excision and choice of the type of surgery are better individualized for each patient and are based on the size of the primary tumor, its location, adherence and fixation to the underlying tissues, its possible extension, through the lymphatic routes, to regional lymph nodes, total number of lesions and the probability to achieve local tumor control [1-3,5,6].

\section{Types of surgical tumor removal}

Surgical options may include: lumpectomy or nodulectomy, simple (single) mastectomy, regional mastectomy, unilateral or bilateral mastectomy [1-3,7]. Surgical techniques based on lymphatic drainage alone are now regarded as an oversimplification since anatomic variability in lymphatic drainage was reported in both normal and neoplastic mammary tumors [8-10].

Lumpectomy or nodulectomy implies removal of benign, small $<0.5-1 \mathrm{~cm}$ in diameter, firm and non adherent or fixed to the skin or underlying tissues nodules [1-3,5]. Lumpectomy is performed by incising the skin over the nodule, which is grasped and separated bluntly from the surrounding parenchyma using mosquito hemostats or scissors (Figure 1 and Figure 2). Excisional biopsy may also be performed by utilizing this technique. Lumpectomy of malignant masses almost always leads to tumor recurrence and should be avoided [2] (Figure 3). In case of malignancy wider clean margins of $2 \mathrm{~cm}$ in all planes are required along with an elliptical incision
Journal of

Veterinary Science \& Medicine

\section{Lysimachos G Papazoglou*, Eleni Basdani, Stefania Rabidi, Michael N Patsikas, Maria Karayiannopoulou}

Department of Clinical Sciences, Companion Animal Clinic, Faculty of Veterinary Medicine, Aristotle University of Thessaloniki, Greece

\section{Address for Correspondence}

Lysimachos G Papazoglou, Department of Clinical Sciences, Companion Animal Clinic, Faculty of Veterinary Medicine, Aristotle University of Thessaloniki, 11 S Voutyra Street, 54627 Thessaloniki, Greece. E-mail: makdvm@vet.auth.gr

Copyright: ๑ 2014 Papazoglou LG, et al. This is an open access article distributed under the Creative Commons Attribution License, which permits unrestricted use, distribution, and reproduction in any medium, provided the original work is properly cited.

Submission: 07 February 2014

Accepted: 17 February 2014

Published: 20 February 2014

Reviewed \& Approved by: Dr. Mark Brown is Professor and faculty in the Department of Clinical Sciences at Colorado State University, USA

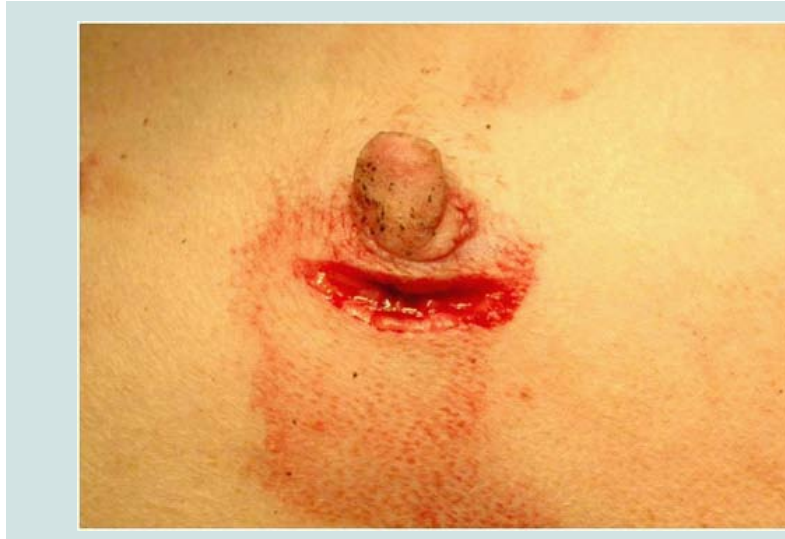

Figure 1: Lumpectomy- A small skin incision is made over the nodule.

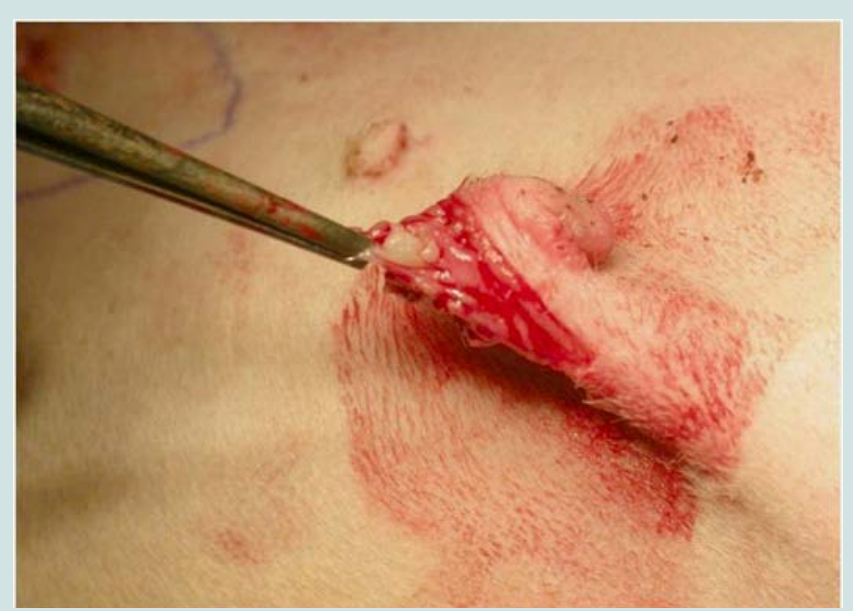

Figure 2: The nodule is grasped with forceps and freed from surrounding tissues. 
Citation: Papazoglou LG, Basdani E, Rabidi S, Patsikas MN, Karayiannopoulou M. Current Surgical Options for Mammary Tumor Removal in Dogs. J Veter Sci Med. 2014;2(1): 6.

ISSN: $2325-4645$

around the overlying skin fixed to the tumor [2]. Following control of hemorrhage the skin is closed with simple interrupted sutures. Simple or single mastectomy is the removal of a single mammary gland and is indicated for large tumors having a central location within the gland and fixed to the overlying skin or the underlying tissues [1$3,5]$. An elliptical skin incision, with $2 \mathrm{~cm}$ margins of normal tissue, is made around the gland (Figure 4 and Figure 5). The abdominal muscle fascia or underlying muscle or abdominal wall should be excised en block if involved. Simple mastectomy performance may be depended on the distinct anatomy of the individual mammary gland. It may be more convenient to remove glands 4 and 5 and glands 1,2 and 3 en block rather than trying to divide merging mammary parenchyma between adjacent glands [5,11]. Regional mastectomy is indicated when large mammary tumors are located in consecutive glands or a tumor is located between two glands (Figure 6 and Figure 7). Regional mastectomy is based on the concept that glands sharing venous and lymphatic drainage may be removed as a unit together with the ipsilateral local lymph nodes [1-3,10]. Thus, glands 1 to 3 and glands 3 to 5 are removed en block along with the ipsilateral inguinal lymph nodes. Lymph node excision is for staging purposes since the presence of positive lymph nodes may affect prognosis of canine mammary carcinomas [3]. Lymph node accessibility and an enlarged node as detected by palpation may help

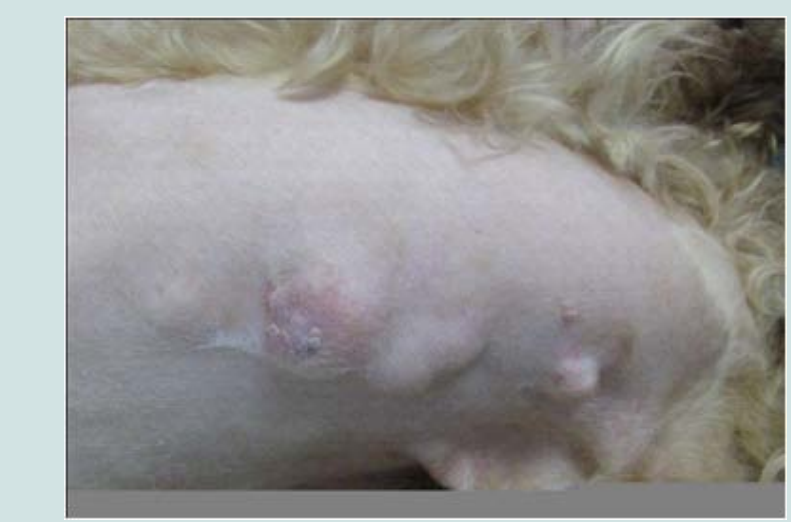

Figure 3: Malignant tumor recurrence following multiple lumpectomies-A unilateral mastectomy is required to revise recurrences.

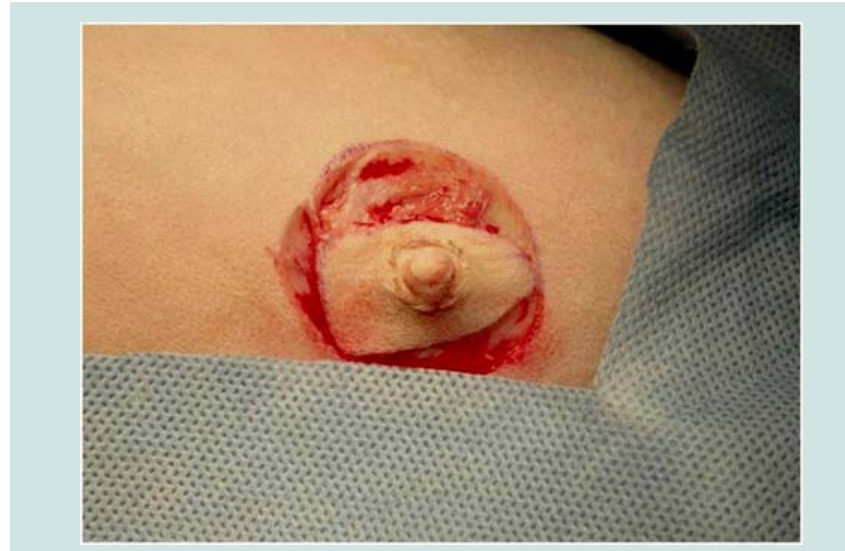

Figure 4: Simple or single mastectomy for removal of a centrally located tumor.

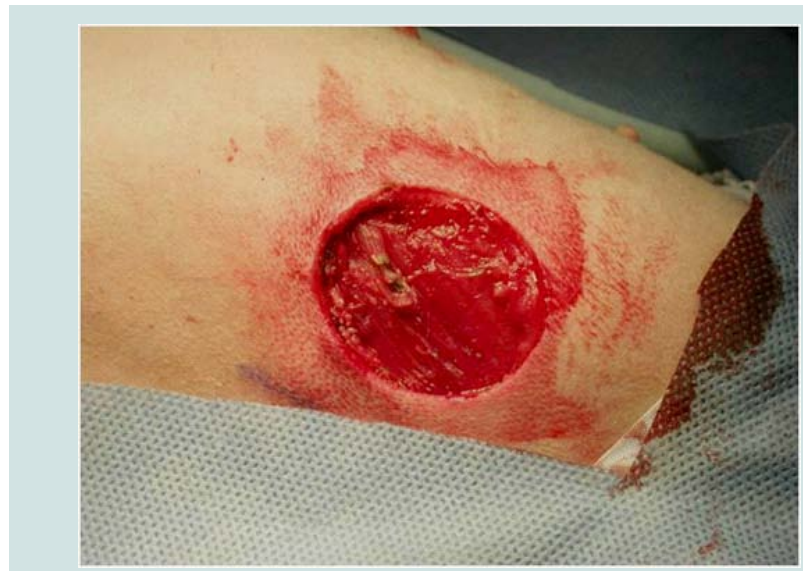

Figure 5: Skin deficit following simple mastectomy of Figure 4.

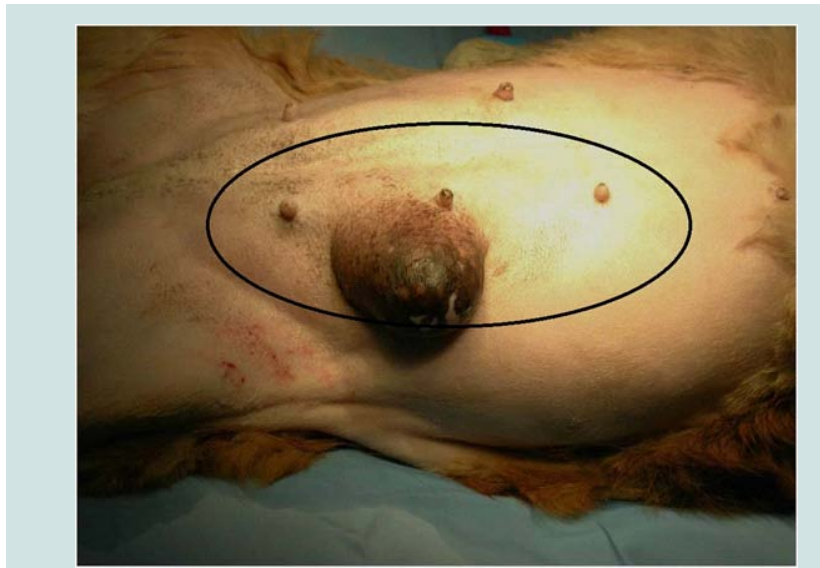

Figure 6: Regional mastectomy. Tumor located between gland 4 and 5 may be removed by regional mastectomy of glands 3,4 and 5 .

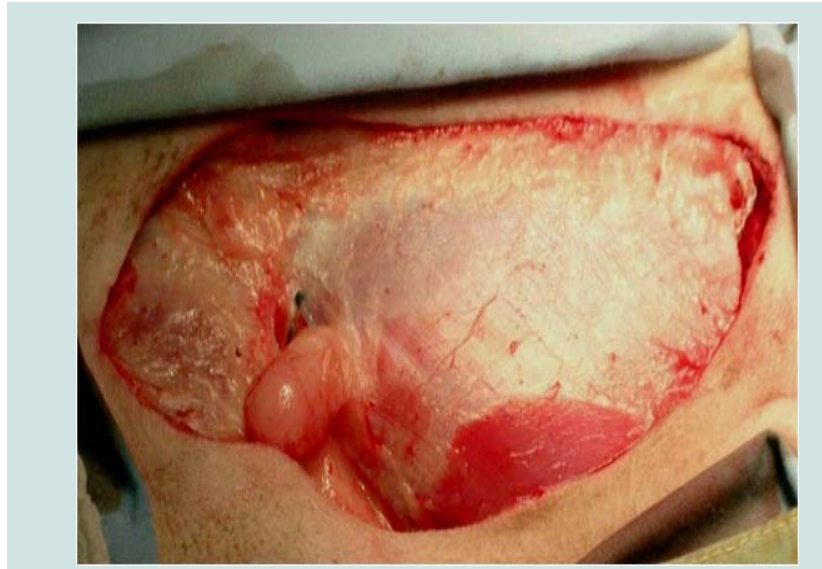

Figure 7: Skin deficit following regional mastectomy of Figure 5

in intraoperative decision making [12]. Thus, removal of the local lymph nodes applies only to superficial inguinal lymph nodes that are excised en block with the gland 5 since they are embedded in the fat attached to this gland. Axillary lymph nodes are removed only if they are enlarged, adherent and fixed to the underlying tissues or if they are cytologicaly or histologicaly invaded by tumor cells $[5,11]$. 
Citation: Papazoglou LG, Basdani E, Rabidi S, Patsikas MN, Karayiannopoulou M. Current Surgical Options for Mammary Tumor Removal in Dogs. J Veter Sci Med. 2014;2(1): 6.

However, mapping of the sentinel lymph nodes in canine mammary tumors has been recently reported using lymphography [10] (Figure 8). Sentinel lymph node mapping may detect which lymph nodes are draining tumor lymph and be at risk of metastasis [10,12] (Table 1). These findings may help surgeons to decide which nodes should be removed intraoperatively along with the mammary tumor using small incisions and the metastatic route of certain histological types of mammary tumors [10]. This technique is especially applied for the not easily accessible axillary lymph node. Sentinel lymph node mapping however, is not considered at the moment as prognostic indicator for canine mammary tumors. Unilateral mastectomy implies removal glands 1 to 5 of a chain as a unit [1-3]. Unilateral mastectomy is indicated for tumors occurring in multiple glands of a chain because sometimes may be quicker and easier to perform than multiple simple mastectomies [11]. When multiple tumors are located in both chains either staged unilateral mastectomies, in a four to six week period, or a simultaneous bilateral mastectomy may be performed at one stage in selected flat-chested animals with loose and pendulous mammary skin [7]. In contrast, in deep-chested dogs a staged unilateral technique may be recommended [13].

Some surgeons favor unilateral mastectomy to prevent recurrence or development of new malignant tumors in young intact dogs with benign atypic lesions $[11,14]$. In contrast, prophylactic bilateral mastectomy to prevent any tumor development is not recommended since it is a very invasive procedure for a healthy animal [15]. Instead, early diagnosis by regular re- examinations and immediate surgical intervention for any new lesion to achieve local tumor control may

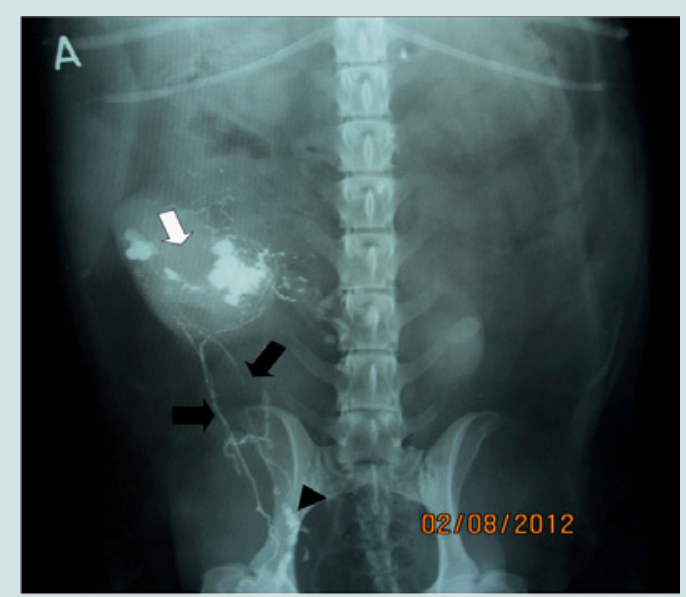

Figure 8: Ventrodorsal lymphograph of a dog with an adenocarcinoma of the gland 3 (white arrow). Lymphatics (black arrows) from this gland proceeded caudally to the superficial inguinal lymph nodes (arrowhead).

Table 1: Lymph drainage of neoplastic mammary glands in the bitch as shown by indirect lymphography [10].

\begin{tabular}{|l|l|}
\hline Mammary gland & Lymph node \\
\hline $1^{\text {st }}$ & Axillary, sternal \\
\hline $2^{\text {nd }}$ & Axillary, sternal \\
\hline $3^{\text {rd }}$ & Axillary, inguinal medial iliac \\
\hline $4^{\text {th }}$ & Inguinal, axillary \\
\hline $5^{\text {th }}$ & Inguinal, popliteal, lymphatic plexus of the thigh \\
\hline
\end{tabular}

be a more realistic option [15]. A recent study reported that $58 \%$ of intact dogs having regional mastectomy for a single tumor removal, exhibited development of a new tumor in the remaining ipsilateral mammary chain after initial surgery that was malignant in $74 \%$ of the dogs [16]. Dogs with an initial malignant tumor were more likely to develop a second malignant tumor ipsilaterally [16]. Based on these findings a unilateral mastectomy is recommended in the hope to prevent a second tumor development [16]. Limitations of this study include that all dogs were intact and might have influenced the possibility of developing a new tumor; in addition, $42 \%$ of dogs of the study population did not develop recurrence and may have undergone an unnecessary second unilateral mastectomy [16]. Authors' recommendations for choosing mastectomy type depending on tumor location and extent are presented in Table 2.

\section{Mastectomy technique}

For mastectomy an elliptical incision of the skin and subcutaneous tissue around the mammary glands involved, with $1-2 \mathrm{~cm}$ margins of healthy tissue, down to the pectoral musculature, abdominal oblique or rectus fascia is made. The medial border of the incision should be the ventral midline. The cranial portion of the skin is elevated and traction is applied caudally; Skin elevation may be assisted by the use of electrosurgery. If the underlying muscle or fascia is not involved and the glands are loosely adherent the mammary chain is stripped from the tissues only by gentle traction. However, excision of the glands 1 and 2 may involve sharp and blunt dissection of the pectoral musculature, whereas glands 3-5 are loosely adherent to the fascia making dissection easier. In case of tumor invasion or fixation to the underlying tissue the plane of dissection should be directed to the next healthy muscle or fascia. Hemorrhage is controlled by electrosurgery. Large vessels that are ligated as encountered include the cranial superficial epigastric and internal thoracic vessels at the level of glands 1 and 2, the caudal superficial epigastric vessels (Figure 9) at the level of the gland 5 and the external pudendal vessels that connect the gland 5 caudally with the perivulvar tissues. Surgical wound lavage with warm saline solution should be performed following excision.

Closure of the surgical wound after mastectomy may be the most challenging part of the surgical procedure and can be accomplished by using various techniques. Dead space obliteration and management of tension in the incision line are the most important issues concerning mastectomy closure [17]. Closure using the conventional technique may be accomplished by absorbable sutures to decrease dead space and tension [17]. Skin edges are undermined and advanced to the center of the wound with simple interrupted or continuous walking sutures using an absorbable monofilament suture material followed by a continuous subcuticular pattern using a similar suture material. Skin closure may be achieved by placement of simple interrupted or cruciate sutures using monofilament nylon or staples. Active or passive drains may be used for the management of dead space.

Skin only closure technique is accomplished by inserting an active suction drain within the surgical wound and by closing the skin with widely placed tension relieving mattress sutures using monofilament nylon; these sutures are preplaced in the skin along the total length of the incision and are tightened following placement [17] (Figure 10). Absorbable walking or subcutaneous sutures are not used with this 
Citation: Papazoglou LG, Basdani E, Rabidi S, Patsikas MN, Karayiannopoulou M. Current Surgical Options for Mammary Tumor Removal in Dogs. J Veter Sci Med. 2014;2(1): 6.

ISSN: $2325-4645$

Table 2: Guidelines for choice of type of surgical excision for canine mammary tumors depending on location and extent $[1-3,5-7,11,13,16,27]$.

\begin{tabular}{|c|c|}
\hline Tumor location & Type of surgical excision \\
\hline Single benign tumor $<0.5-1 \mathrm{~cm}$ & Lumpectomy or nodulectomy \\
\hline $\begin{array}{l}\text { Multiple benign or malignant tumors } \\
<0.5-1 \mathrm{~cm} \text { in one or both chains }\end{array}$ & $\begin{array}{l}\text { Unilateral/ regional mastectomy- } \\
\text { staged or concurrent bilateral } \\
\text { mastectomies }\end{array}$ \\
\hline $\begin{array}{l}\text { Multiple large tumors in one or both } \\
\text { chains }\end{array}$ & $\begin{array}{l}\text { Regional/unilateral mastectomy- } \\
\text { staged or concurrent bilateral } \\
\text { mastectomies }\end{array}$ \\
\hline Single large tumor in one gland & Regional or unilateral mastectomy \\
\hline $\begin{array}{l}\text { Single large tumor with central } \\
\text { location in one gland with distinct } \\
\text { anatomic boundaries }\end{array}$ & $\begin{array}{l}\text { Simple mastectomy/regional or } \\
\text { unilateral mastectomy }\end{array}$ \\
\hline $\begin{array}{l}\text { Malignant tumor adhered to underlying } \\
\text { tissues }\end{array}$ & $\begin{array}{l}\text { Regional or unilateral mastectomy } \\
\text { incorporating muscle/fascia }\end{array}$ \\
\hline $\begin{array}{l}\text { Tumor/tumors in adjacent glands or } \\
\text { between glands }\end{array}$ & Regional or unilateral mastectomy \\
\hline $\begin{array}{l}\text { Tumors located in or between glands } \\
1,2 \text { and } 3\end{array}$ & $\begin{array}{l}\text { Regional mastectomy of glands } 1-3 \\
\pm \text { axillary node removal or unilateral } \\
\text { mastectomy }\end{array}$ \\
\hline $\begin{array}{l}\text { Tumors located in or between glands } \\
3,4 \text { and } 5\end{array}$ & $\begin{array}{l}\text { Regional mastectomy 3-5 + inguinal } \\
\text { node removal or unilateral mastectomy }\end{array}$ \\
\hline
\end{tabular}

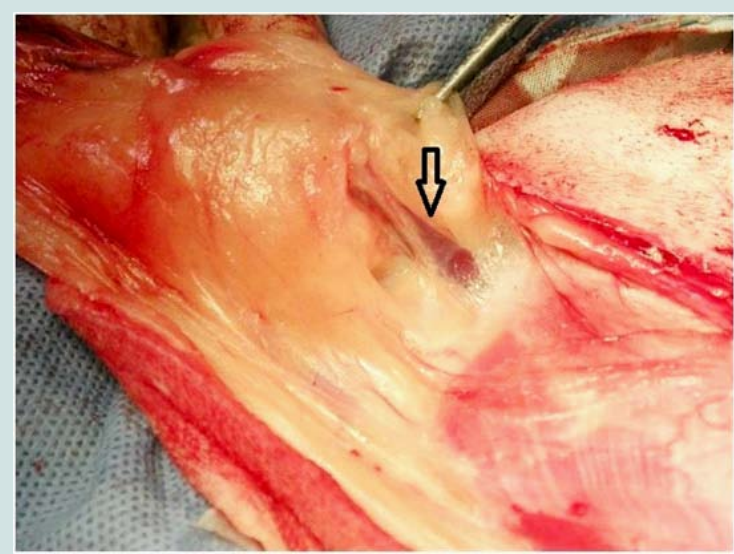

Figure 9: Caudal superficial epigastric vessels are isolated under a hemostat.

technique [17]. Simple interrupted, cruciate sutures or staples that are placed inside each mattress suture are used to complete the skin closure [17]. The drain exit is close to the incision and is secured to the skin with a Chinese finger trap suture pattern. If a drain is used the incision is covered by a soft pad secured in place with a stockinette bandage placed around the thorax, abdomen and inguinal region for the protection of the incision and drain device [17]. The reservoir bag of the active drain is secured under the stockinette bandage.

In case of large mastectomy wounds created mainly after bilateral excisions or following large tumor excision in the medial thigh or sternum bilateral or unilateral skin fold flaps may be used respectively to cover these defects [18] (Figure 11 and Figure 12).

After mastectomy the whole resected tissue should be submitted for histopathological examination to provide tumor classification since many different tumor types (malignant vs benign) may be encountered in the same surgical specimen. Histopathological examination is also necessary for surgical margin evaluation.
Although early ovariohysterectomy (OHE) in dogs has been definitely demonstrated to prevent the risk of tumor development, the role of concurrent or post mastectomy OHE is still unclear $[19,20]$. In one study concurrent or post mastectomy OHE had no effect on survival [21]. However, other authors demonstrated improved survival when OHE is performed in less than 2 years before or at the same time with mastectomy $[3,22]$.Young animals may be

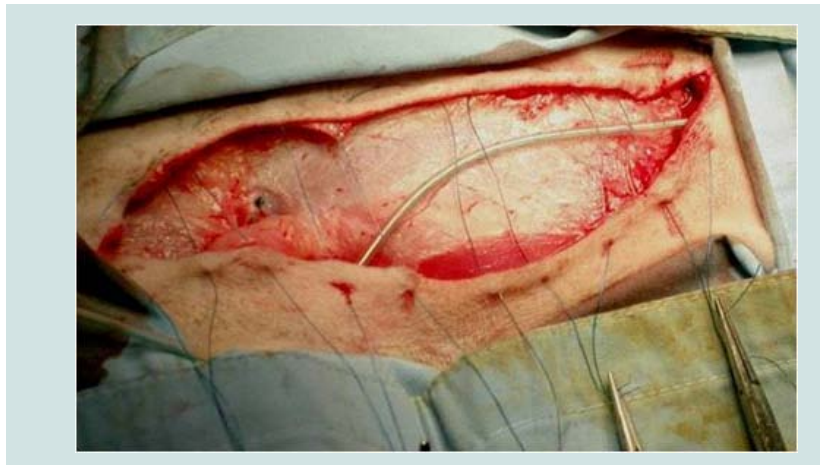

Figure 10: Only skin closure technique following regional mastectomy in a dog. Widely preplaced horizontal mattress nylon sutures held with hemostats were put under an active drain.

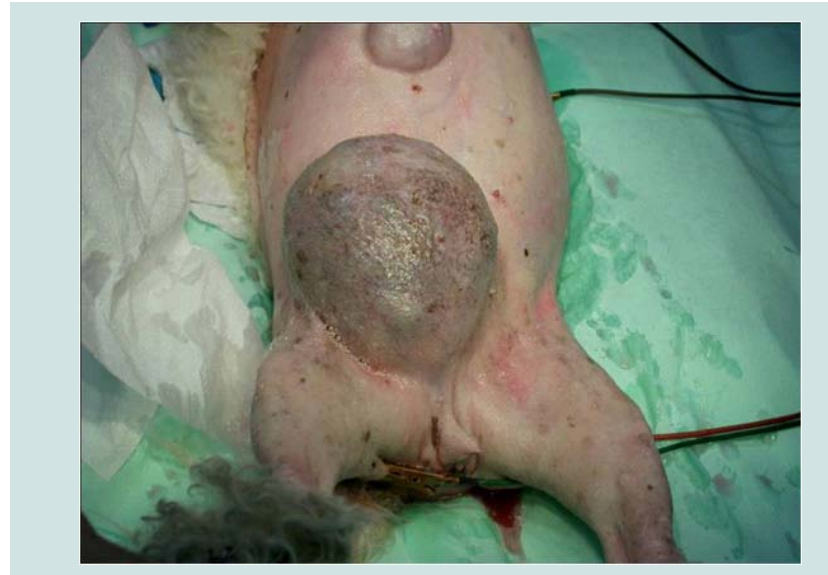

Figure 11: Mammary tumors in glands 3 and 5 in a bitch.

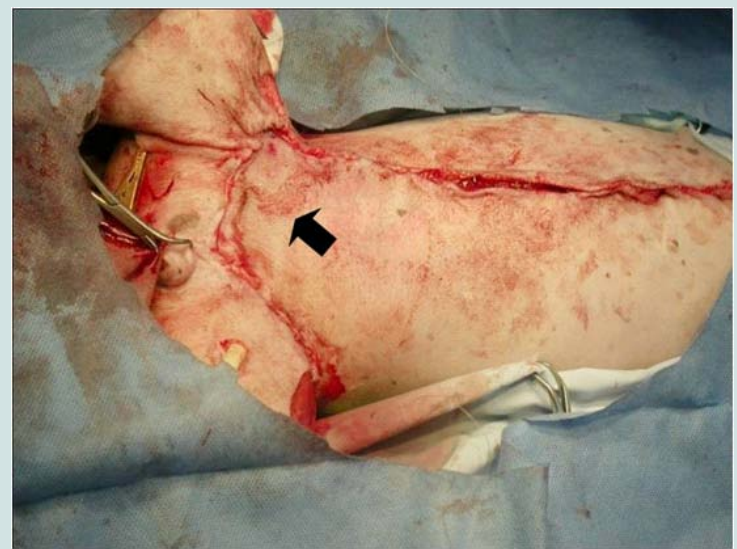

Figure 12: Closure of regional mastectomy performed in dog of figure 11 by the aid of a unilateral skin fold flap (black arrow). 
Citation: Papazoglou LG, Basdani E, Rabidi S, Patsikas MN, Karayiannopoulou M. Current Surgical Options for Mammary Tumor Removal in Dogs. J Veter Sci Med. 2014;2(1): 6.

ISSN: $2325-4645$

benefit from concurrent OHE to prevent development of new benign tumors and to achieve a decrease of active mammary tissue allowing for an easier later mastectomy [23].

Analgesia with opioids should be provided in all dogs undergoing mastectomy incisions [17]. Pre-emptive administration of meloxicam $(0.2 \mathrm{mg} / \mathrm{kg} \mathrm{sc})$ or postoperative administration of ketamine $(700 \mu \mathrm{g} /$ KG iv) followed by a 6 hour ketamine $(10 \mu \mathrm{g} / \mathrm{kg})$ at a constant rate infusion seem to provide adequate analgesia postmastectomy in dogs $[24,25]$. Mastectomy wound infiltration with bupivacaine in one preoperative dose or as a continuous wound infiltration may show promise in providing postoperative analgesia in dogs as it has been demonstrated in laparotomy incisions [26].

In a recent study we compared dogs with only skin closure technique with a drain versus dogs with conventional closure with a drain and dogs with conventional closure without a drain; it was demonstrated that duration of surgery was significantly shorter for dogs with only skin closure technique, fluid collected in the drain reservoir bag and duration of drainage was not different between the groups and duration of hospitalization was not significantly different for the dogs of all groups [17] (Table 3). Bandage changes may be performed at regular intervals [17]. Active drains are removed within $1-3$ days after surgery as soon as the fluid collection in the reservoir bag is minimal [17]. All sutures are removed 10 days after surgery [17].

\section{Complications}

Postmastectomy related complications may include seroma formation, wound infection, dehiscence of the incision, ischemic necrosis, self-mutilation, hemorrhage, hind limb edema, and tumor recurrence $[2,16,17,27-29]$. Seroma or hematoma formation is not uncommon and is associated with inadequate dead space elimination or problematic drainage [17]. Drains may incite fluid formation as much as $50 \mathrm{ml}$ depending on the drain size and wound size created [30,31]. Postoperative acute hemorrhage was also reported in dogs following active drain placement [32]. The effect of dead space obliteration on seroma formation in mastectomy wounds in humans was studied and it was reported that fluid collection was significantly diminished when active drains were used compared to a control group [33]. In a recent study, in order to identify the necessity of

Table 3: Comparison of conventional mastectomy closure with closed suction drainage (CMC), skin-only closure with closed suction drainage (OSC) and a conventional closure group without any drain placement (CNDC) in 60 dogs underwent regional or unilateral mastectomies for the management of mammary tumors. Data are presented as mean \pm SD [17]. Asterisk denotes significant differences.

\begin{tabular}{|l|l|l|l|}
\hline Parameters & CMC & OSC & CNDC \\
\hline $\begin{array}{l}\text { Duration of } \\
\text { procedure } \text { (min) }\end{array}$ & $\begin{array}{l}29.30 \pm 10.12 \\
\text { (median 27.50; } \\
\text { range, 15 to 60) }\end{array}$ & $\begin{array}{l}22.55 \pm 7.62 * \\
\text { (median 20; range, } \\
15 \text { to 40) }\end{array}$ & $\begin{array}{l}28.7 \pm 8.56 \\
\text { (median 26.5; } \\
\text { range, 20 to 45) }\end{array}$ \\
\hline $\begin{array}{l}\text { Volume of fluid } \\
\text { collected } \\
\text { in the reservoir } \\
\text { bag } \text { (mL) }\end{array}$ & $\begin{array}{l}19.00 \pm 16.40 \\
\text { (median 15; range } \\
1 \text { to 60) }\end{array}$ & $\begin{array}{l}41.50 \pm 46.416 \\
\text { (median 20; range, } \\
2 \text { to 160) }\end{array}$ & - \\
\hline $\begin{array}{l}\text { Duration of } \\
\text { drainage (days) }\end{array}$ & $\begin{array}{l}1.55 \pm 0.51 \\
\text { (range, } 1 \text { to 2) }\end{array}$ & $\begin{array}{l}1.45 \pm 0.60 \\
\text { (range, 1 to 3) }\end{array}$ & - \\
\hline $\begin{array}{l}\text { Duration of } \\
\text { hospitalization } \\
\text { (days) }\end{array}$ & $\begin{array}{l}2.15 \pm 0.74 \\
\text { (range, } 1 \text { to 3) }\end{array}$ & $\begin{array}{l}2.15 \pm 0.87 \\
\text { (range, 1 to 4) }\end{array}$ & $\begin{array}{l}1.2 \pm 0.41 \text { (range, } \\
1 \text { to 2) }\end{array}$ \\
\hline
\end{tabular}

active drain placement in mastectomy wounds, a group of dogs that had a conventional mastectomy closure without drain placement was compared to a conventional mastectomy group with a drain and with an only skin closure group with a drain [17]. Based on the findings of this study it was demonstrated that when the conventional mastectomy closure is used and provided that Halsted's principles are followed and dead space is obliterated with sutures use of a drain is not necessary [17]. In the same study it was found that the type of mastectomy (regional vs unilateral) had no effect on the amount of fluid collected in the reservoir bag [17].

Dehiscence of the incision line associated with tension may be seen in bilateral or unilateral or regional mastectomies especially in the inguinal region [17]. With minimal dehiscence the wound is allowed to heal by second intention. Development of secondary irreducible malignant lymphedema located in the hind limbs was documented in dogs after having mastectomy for a malignant tumor. Lymphedema formation was attributed to lymphatic obstruction by neoplastic cells following mastectomy incision [34].

\section{References}

1. MacEwen EG, Hayes AA, Harvey HJ, Patnaik AK, Mooney S, et al. (1984) Prognostic factors for feline mammary tumors. J Am Vet Med Assoc 185 201-204.

2. Allen SW, Mahaffey EA (1989) Canine mammary neoplasia: prognostic indicators and response to surgical therapy. J Am Anim Hosp Assoc 25: 540546.

3. Chang SC, Chang CC, Chang TJ \& Wong ML (2005) Prognostic factors associated with survival two years after surgery in dogs with malignant mammary tumors: 79 cases (1998-2002). J Am Vet Med Assoc 227: 16251629.

4. Marconato L, Romanelli G, Stefanello D, Giacobini C, Bonfanni U, et al. (2009) Prognostic factors for dogs with mammary inflammatory carcinoma: 43 cases (2003-2008). J Am Vet Med Assoc 235: 967-972.

5. Nimwegen van S, Kirpensteijn J (2012) Specific disorders. In: Veterinary Surgery Small Animal. Tobias KM, Johnston SA, St Louis Elsevier.

6. Soremno KU, Worley DR, Goldschmidt H (2013) Tumors of the mammary gland. In: Small Animal Clinical Oncology. Withrow SJ, Vail DM, Page RL (5 $5^{\text {th }}$ Edition), St Louis, Elsevier.

7. Bartels KE, Ferguson HR, Gillette EL, Ferguson HL (1978) Simultaneous bilateral mastectomy in the dog. Vet Surg 7: 97-102.

8. Patsikas MN, Dessiris A (1996a) The lymph drainage of the mammary glands in the bitch: a lymphographic study. Part I: The $1^{\text {st }}, 2^{\text {nd }}, 4^{\text {th }}$ and $5^{\text {th }}$ mammary glands. Anat Histol Embryol 25: 131-138.

9. Patsikas MN, Dessiris A (1996b) The lymph drainage of the mammary glands in the bitch: a lymphographic study. Part II: The $3^{\text {rd }}$ mammary gland. Anat Histol Embryol 25:139-143.

10. Patsikas MN, Karayannopoulou M, Kaldrymidou E, Papazoglou LG Papadopoulou PL, et al. (2006) The lymph drainage of the neoplastic mammary glands in the bitch: a lymphographic study. Anat Histol Embryol 35: 228-234.

11. Lana S, Rutteman GR, Withrow SJ (2007) Tumors of the mammary gland. In: Withrow and MacEwen's Small Animal Clinical Oncology. $4^{\text {th }}$ Edition, Withrow SJ, Vail DM, St. Louis, Saunders Elsevier.

12. Tuohy JL, Milgram J, Worley DR, Dernell W (2009) A review of sentinel lymph node evaluation and the need for its incorporation into veterinary oncology. Vet Comp Oncol 7: 81-91.

13. Stone EA (2000) Mammary gland neoplasia. In: Saunders Manual of Small Animal Practice. (2 ${ }^{\text {nd }}$ Edition), Birchard SJ, Sherding RG, Philadelphia, WB Saunders Co. 
Citation: Papazoglou LG, Basdani E, Rabidi S, Patsikas MN, Karayiannopoulou M. Current Surgical Options for Mammary Tumor Removal in Dogs. J Veter Sci Med. 2014;2(1): 6.

ISSN: $2325-4645$

14. Gilbertson SR, Kurzman ID, Zachrau RE, Hurvitz AI, Black MM (1983) Canine mammary epithelial neoplasms: biological implications of morphologic characteristics assessed in 232 dogs. Vet Pathol 20: 127-142.

15. Polton G (2009) Mammary tumours in dogs. Irish Vet J 62: 50-56.

16. Stratmann N, Failing K, Richter A, Wehrend A (2008) Mammary tumor recurrence in bitches after regional mastectomy. Vet Surg 37: 82-86.

17. Papazoglou LG, Tsioli V, Karayannopoulou M, Savvas I, Kazakos G, Kaldrymidou E (2006) Comparison of three methods for closure of mastectomy incisions in dogs. Aust Vet Pract 36: 156-162.

18. Hunt GB (1995) Skin fold advancement flaps for closing large sternal and inguinal wounds in dogs and cats. Vet Surg 24: 172-175.

19. Schneider R, Dorn RC, Taylor DON (1969) Factors influencing canine mammary cancer development and postsurgical survival. J Natl Cancer Inst 43: $1249-1261$.

20. Taylor GN, Sahestari L, Williams J, Mays WA, Angus W, et al. (1976) Mammary neoplasia in a closed beagle colony. Cancer Res 36: 2740-2743.

21. Philibert JC, Snyder PW, Glickman N, Glickman LT, Knapp W, et al. (2003) Influence of host factors on survival in dogs with malignant mammary gland tumors. J Vet Intern Med 17: 102-106.

22. Soremno KU, Shofer FS, Goldschmidt M (2000) Effect of spaying and timing of spaying on survival of dogs with mammary carcinoma. J Vet Intern Med 14: 266-270.

23. Rutteman GR, Misdorp W (1993) Hormonal background of canine and feline mammary tumours. J Reprod Fertil Suppl47: 483-487.

24. Nakagawa K, Miyagawa Y, Takemura N, Hirose H (2007) Influence of preemptive analgesia with meloxicam before resection of the unilateral mammary gland on postoperative cardiovascular parameters in dogs. J Vet Med Sci 69: 939-944.
25. Sarrau S, Jourdan J, Dupuis-Soyris F, Verwaerde P (2007) Effects of postoperative ketamine infusion on pain control and feeding behaviour in bitches undergoing mastectomy. J Small Anim Pract 48: 670-676.

26. Savvas I, Papazoglou LG, Kazakos G, Anagnostou T, Tsioli V, et al. (2008) Incisional block with bupivacaine for analgesia after celiotomy in dogs. J Am Anim Hosp Assoc 44: 60-66.

27. MacPhail CM (2013) Surgery of the female reproductive tract. In: Small Animal Surgery. $4^{\text {th }}$ Edition, Fossum TW, St. Louis, Mosby Elsevier.

28. Birchard SJ (1995) Definitive surgical treatment for cancer. In: Kirk's Current Veterinary Therapy XII. Bonagura JD, Philadelphia, Saunders

29. Harvey HJ (1998) Mastectomy. In: Current Techniques in Small Animal Surgery. $4^{\text {th }}$ Edition, Bojrab MJ, Philadelphia, Lea and Febiger.

30. Fox JW, Golden GT (1976) The use of drains in subcutaneous surgical procedures. Am J Surg 132: 673-674.

31. Lee AH, Swaim SF, Henderson RA (1986) Surgical drainage. Comp Cont Educ Pract Vet 8: 94-103.

32. Lynch AM, Bound NJ, Halfacree ZJ, Baines S (2011) Postoperative haemorrhage associated with active suction drains in two dogs. J Small Anim Pract 52: 172-174.

33. Coveney EC, O Dwyer PJ, Geraghty JC, O Higgins NJ (1993) Effect of closing dead space on seroma formation after mastectomy - a prospective randomized clinical trial. Eur J Surg Oncol 19: 143-146.

34. Kang JH, Lee JY, Mo IP, Lee WG, Chang DW, et al. (2007) Secondary malignant lymphoedema after mastectomy in two dogs. J Small Anim Pract 48: 579-583. 